\title{
SOBRE A RECEPÇÃO DE OS LUSÍADAS EM FRANÇA ATÉ AO SÉCULO XVIII
}

Sérgio Paulo Guimarães de Sousa Universidade do Minho

Para a Cátia

\section{Introdução}

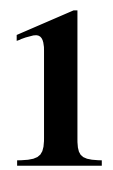

.1. Não é nossa pretensão um investimento que adicione algo de novo relativamente à recepção de Os Lusiadas em França até ao século XVIII. Correríamos, se objectivassemos tal finalidade, o risco de nos expormos a justas acusações de pretensiosismo e sensacionalismo. Descobrir matéria nova relativa a este tema exigiria, além da eficácia de rigorosas investigações em bibliotecas francesas, um factor incontrolável: o factor sorte, que, por vezes, recompensa, com muita razão de ser, os que notoriamente se dedicam ao estudo e à divulgação de Luís de Camões por terras gaulesas.

Desejamos, então, com este breve estudo, tão só contribuir para a criação de uma imagem unitária da fortuna da epopeia camoniana em França até 1800. Unir o disperso já existente pode parecer uma tarefa pouco profícua do ponto de vista dos estudos literários, pois nada de novo surge, apenas se "retalha" num mesmo tecido textual o que vários estudiosos da temática espalharam em artigos e ensaios. Contudo, a grandeza ímpar de Camões parece abrir uma excepção. Camões há muito que deixou de pertencer às nossas estreitas fronteiras. Trata-se de um autor de dimensão mundial, "um autor muito estudado na União Europeia e nos Estados Unidos, cujas universidades o integram nos seus planos curriculares", para além dos estudos camonianos serem "uma das cadeiras mais procuradas 
pelos alunos estrangeiros"que estudam em Portugal, como assinala Aníbal Pinto Castro. ${ }^{1}$ Camões é património da humanidade, ao lado de Cervantes, Shakespeare, Dante... e poucos mais. Para compreendermos o fenómeno camoniano na sua dimensão receptiva, seja em que cultura for, teremos necessariamente de retroceder até à génese desse fenómeno, i.e., proceder à reconstituição, o mais rigorosamente possível, o historial da difusão do poeta e da epopeia que o projectou para um lugar cimeiro do cânone da Grande Literatura. Estamos seguros de que entenderemos muito melhor o vivo interesse que Camões e Os Lusíadas suscitam em qualquer parte do mundo, se compreendermos a origem desse interesse, da mesma forma que o entendimento da nossa História e da nossa Cultura pressupõe olharmos para as nossas raízes histórico-culturais.

De resto, traçar um quadro unificador da recepção literária de Os Lusíadas num contexto extra-nacional constitui (mais) uma forma de potenciar o enaltecimento de Camões, progenitor de uma obraprima, cuja mundialização actual não decorre da globalização imprimida no quotidiano humano pelas recentes tecnologias de natureza cognitiva, mas procede de incursões iniciadas, no caso da França, no século XVII, ainda que de uma forma pouco auspiciosa.

1.2. Considerando-se o fenómeno de natureza artística um complexo produto expressivo gerador de fascinação, entendível em termos de projecção-identificação individual e transindividual, diríamos ter sido esse o resultado das primeiras leituras e assimilações nacionas de Os Lusíadas. De facto, aquando da sua publicação em 1572, a epopeia camoniana preencheu uma lacuna no panorama literário nacional. O desejo latente de um retorno ao género épico e a necessidade de se contarem as proezas heróicas dos Portugueses, maiores do que as dos heróis clássicos, permitiram causar, favoralmente na consciência receptiva dos leitores da época,

${ }^{1}$ apud QUEIRÓS, 1996, p.29. 
fruição estética, realizando em cada um "la possibilité de renouveler sa perception de la réalité tant intérieure qu'extérieure (...)". ${ }^{2}$

Quanto à recepção francesa, levem-se, do ponto de vista teorético, em consideração as propostas de Maria Manuela Delile e Maria Teresa Delgado Mingocho (cf. 1980), que justamente advogam a legitimidade de uma dupla recepção estética: uma recepção produtiva e uma recepção valorativa. O conceito de recepção produtiva refere-se ao processo de produção de uma obra motivada pela recepção de outra(s), o de recepção valorativa diz respeito à emissão de juízos de valor relativos à obra em recepção. Os Lusíadas até 1800 foram alvo em França de uma recepção essencialmente valorativa, embora sejam vários os exempla de recepção produtiva. Citemos, entre outros, os de dois autores menores: Roucher e Mme de Genlis. O primeiro serviu-se mimeticamente do episódio do "Adamastor" para a produção dos poemas "Avril" e "Décembre", publicados na obra Les Mois, poème en 12 chants... em 1779. Mme de Genlis em Les Veillées du Château ou Cours de Morale (1784) contextualizou espacialmente a vivência do herói do episódio, intitulado "Alphonse et Dalinde ou la Féérie de l'art", na Fontaine des Amours que lembra, por demais, a "Ilha dos Amores". Contudo, o episódio camoniano que mais fertilizou a literatura francesa e europeia, nos seus diferentes géneros, é o de Inês de Castro que, pelo seu conteúdo de teor romanesco, gerou uma enorme receptividade a nível da produção de obras.

No entanto, até ao século XIX foram as referências e os comentários valorativos de Os Lusiadas que marcaram realmente presença. As traduções da epopeia também se inserem neste âmbito, pois os tradutores não se inibiram de formular opiniões e apreciações críticas que, em alguns casos, condicionaram a própria tradução, diminuindo a obra no seu valor estético-literário.

${ }^{2}$ JAUSS, 1979, p.272. 
Estas "leituras negativas" de Camões, que reduzem substancialmente a plurissignificância do texto, podem levar-nos ingenuamente (e a priori), a estigmatizarmos a experiência estética da sua recepção como possibilidade negativa. Ver-se-á isso em recepções pautadas por (i) críticas injustamente corrosivas e por (ii) traduções abusivas ao sabor de preconceitos de natureza histórico-social. Em ambos os casos, relega-se para um plano inferior ou até se anula - no caso das traduções abusivas - marcas semiótico-discursivas relevantes para a "polivalência" textual camoniana. Uma conotação negativa do processo de recepção, na sua globalidade diacrónica, será, contudo, infundada, na medida em que o valor literário da epopeia de Camões não radica, apenas, na leitura parcial que dela fez, por exemplo, Voltaire, mas resulta da súmula das várias actividades leiturais que a história se encarregou de prosseguir, a maior parte das quais mais ajustadas e menos licenciosas do que a deste iluminista hermeneuticamente pouco iluminado. Aliás, como observa Horst Steinmetz, a propósito do fenómeno da recepção e da interpretação: "Les conditions du sens et des significations sont positivement comme négativement limitées par les systèmes de sens et les normes du récepteur."

Deste modo, se explica um Frei Bartolomeu Ferreira, apesar de censor do Santo Ofício, tolerante e complacente com os "Deoses de Gentios" e um Voltaire, apesar de iluminista, chocado perante interferências pagãs.

Mas o importante, em qualquer trabalho comparativista, prende-se, como notam Álvaro Manuel Machado e Daniel-Henri Pageaux ${ }^{4}$ com o descortinar das circunstâncias em que se processou determinada interpretação ou leitura, ou mesmo valoração judicativa. Tentaremos conduzir o nosso estudo de forma a que se vise este princípio.

${ }^{3}$ STEINMETZ, 1981, p.200.

${ }^{4}$ MACHADO e PAGEAUX, 1988, P.84-5. 


\section{Séculos XVII e XVIII: Camões em referência}

É consensual atribuir-se ao jesuíta René Rapin a estreia de Camões em França numa obra intitulada Réflexions sur la Poétique d'Aristote et sur les ouvrages des poètes anciens et modernes, publicada em Paris no ano de 1674. Contudo, foi nesse mesmo ano que veio a público a primeira edição do Grand Dictionnaire Historique ou le Mélange Curieux de l'Histoire Sacrée et Profane (Lyon, J. Guérin e B. Rivière, in-fol., 1346 p.) de Louis Moreri, com um longo artigo sobre a vida e a obra épica do poeta. Qual dos dois terá primeiro mencionado o nome de Camões? A coincidência de datas não permite, em nosso entender, tomar partido, apesar de R. Rapin ser tido, pela crítica, como o legítimo introdutor de Camões em França.

Notemos que quando R. Rapin se refere discretamente a Camões, ainda não se sonhava traduzir Os Lusiadas em língua francesa. E se as suas fontes não se restringem ao artigo de Moreri, então, ou o jesuita conhecia o idioma português ou terá acedido a informações sobre Os Lusiadas a partir de eruditos que conheciam a nossa língua.

$\mathrm{Na}$ verdade e em rigor, o nome de Camões encontrava-se já presente no contexto francês pela pena de outro grande génio da cultura ocidental: Miguel Cervantes Saavedra. Em O Engenhoso Fidalgo Dom Quixote de la Mancha, Camões merece, no capítulo 58, uma breve, mas explícita, referência: "(...) trazemos estudadas duas eclogas, uma do famoso poeta Garcilaso e outra do sublime Camões, na sua propria lingua portugueza."

Cervantes, admirador de Camões, teve o bom senso de o divulgar, associando o nome pouco conhecido do poeta português ao conhecido Garcilaso de La Vega. Em 1618, os leitores franceses já dispunham de uma tradução das aventuras do cavaleiro andante,

5 SAAVEDRA, 1878, p.385. 
intitulada L'ingénieux et redoutable chevalier Dom Quixote de la Manche... Seguiram-se reedições em 1622, 1639, 1646, 1655. É provável que R. Rapin cruzasse Camões disfrutando a leitura de uma delas. Outra alternativa prende-se com a oportunidade de encontrar Camões em l'Apollon ou l'Oracle de la poésie italienne et espagnole (1644) de P. Bense-Dupuis, onde a propósito de um soneto de Lope da Vega, se alude ao poeta português; ou então pela mão de Francisco Alcofrado em Relation historique de la découverte de l'̂̂le de Madère, trad. du portugais (1671), obra na qual se menciona Camões ao falar-se do seu "illustre commentateur" Faria e Sousa, que enceta comentários "sur la cinquième stance de ce Prince des Poètes espagnols". Mas é ainda possível que Rapin, tal como Moreri, tivesse descoberto o poeta luso num artigo da Bibliotheca hispana nova sive Hispanorum de Nicolao Antonio, editada em 1672.

B. Xavier Coutinho ${ }^{6}$ defende que, bem antes de Nicolau António, Camões já se contextualizava no universo francês, por obra dos diplomatas de João IV, enviados para a corte do Rei Sol. O conde de Vidigueira, embaixador e descendente de Vasco da Gama, teria sido um dos difusores de Os Lusíadas. Coutinho cita uma carta "aussi curieuse que mal écrite", datada de 21 de Março de 1641, escrita por um tal de Soares de Abreu aos irmãos Godfroy para demonstrar que sob Luís XIV "Partout Camoens était mis à l'ordre du jour":

Monsieur,

Je vous prie de vous écrire dorénavant en toute liberté sur laquelle anticipant je commencerai le premier, \& présente ensemble ici deux livres de Louis de Camoens, grand poète Portugais, un pour vous et l'autre pour M. de Sainte Marthe; vous me ferez la faveur de le faire tenir en ses mains, avec mes biens humbles remerciements. Le Don est petit, mais je sais que vous le jugerez à propos en ceste occasion car il est un poème bien fait, la matière et le sujet duquel estant le fondateur de la trez illustre maison de Mr. le Comte de Vidigueira, admiral des mers de l'Inde et nostre Ambassadeur.

${ }^{6} \mathrm{cf}$. COUTINHO, 1941, p.65-6. 
Apesar destas primeiras tentativas de mostrar o nosso grande épico, e, ainda por cima, num contexto espacial tão propenso a novidades como era a corte francesa seiscentista, Coutinho não deixa de reconhecer que “(...) Dès 1640, Camoens faisait son chemin péniblement".

Porém, foi R. Rapin, pela ressonância que teve na cultura francesa, enquanto teórico literário, independentemente da justeza ou não das suas considerações valorativas sobre Os Lusiadas, em boa verdade, um dos primeiros difusores do poeta. As obras deste literato foram várias vezes reimpressas ao longo do século XVIII, contribuindo bastante para despertar um progressivo interesse pelo nosso Virgílio, mesmo a despeito de considerações pouco abonatórias a Camões, como esta: "Le Camoens, qui est le seul Poète héroique de Portugal, n'a pensé qu'à exprimer l'orgueil de sa nation en son Poème de la conqueste des Indes. Car il est fier \& fastueux dans sa composition, mais il a peu de conduite". ${ }^{8}$

Rapin não menciona o nome da epopeia que avalia. Limitase a designá-la pelo "poème de la conquête des Indes". É, por essa razão, provável que não tenha lido Os Lusíadas. É igualmente um indício de que as suas críticas não têm por base as de Moreri, uma vez que este último intitula o poema, apesar de lhe mudar o género. Impressiona deveras que um conceituado estudioso das letras, como o foi Rapin, se pronunciasse tão dogmatica e severamente sobre um objecto textual que nunca terá lido. Essa lacuna não o de escrever coisas assim: "C'est en quoi le Camoens, que les Portugais appelent leur Virgile, est blâmable, car ses vers sont si obscurs qu'ils pouraient passer pour des mystères".?

\footnotetext{
7 COUTINHO, 1941, p.67.

${ }^{8}$ apud COUTINHO, 1982, p.515.

9 apud BISMUT, 1981, p.729.
} 
Mas não é só a ausência de inteligibilidade e clareza que o jesuita censura ao Virgílio português, a grandeza temática abordada por Camões também incomoda:

Les gens qui embrassent trop, ne font rien d'exact; tout ce qu'ils disent \& ce qu'ils imaginent n'est point réglé; ils n'ont ny proportion dans le dessein, ny justesse dans la pensée, ny exactidude dans l'expression (...) comme Diego Ximenes dans son Poème du Cid Ruy Dias Bivar et le Camoens dans la conquête des Indes par les Portugais. ${ }^{10}$

O mesmo acontece com a ficcionalidade. Se ela é essencial na ascensão do comum ao admirável e extraordinário, no poema épico ela deve reger-se por uma "juste convenance" e uma "parfaite liaison" que permite uma justa proporção de todas as partes da obra. Mais um terrível erro a denunciar: "Camoens qui parle sans discrétion de Vénus, de Bacchus \& des autres divinitez profanes dans un poème Chrétien". ${ }^{11}$

Soa-lhe a falso. Resta-nos a consolação de sabermos que Rapin também desconsiderou, munido do seu "espírito crítico vesgo e deficiente" 12 , Ariosto e Boiardo. O único mérito apontável neste crítico, além da referência a Camões, provém deste elucidar a origem portuguesa do poeta, o que não evitou que Juvenal de Carlencas, homem de cultura, escrevesse: "Comme les Espanhols outrent toujours tous les sujets qu'ils traîtent, il n'y a pas lieu de s'etonner que Louis de Gongora et le Camoens passent les bornes du bucolique". ${ }^{13}$

Quanto a Moreri, foi também ele um importante divulgador de Camões, ao atribuir-lhe um lugar nas páginas 741 e 742 do seu Grand dictionnaire historique ou le Mélange curieux de l'bistoire

\footnotetext{
${ }^{10}$ apud COUTINHO, 1941, p.59.

${ }^{11}$ apud COUTINHO, 1982, p.517.

12 apud COUTINHO, 1982, p.517.

13 apud PAGEAUX, 1871, p.38.
} 
sacrée et profane (1674). A fortuna invulgar desta obra na cultura literária dos séculos XVII e XVIII foi determinante para a difusão do poeta.

Xavier Coutinho ${ }^{14}$, preocupado em acentuar que Rapin escreveu o que escreveu sobre Camões, porque assim o leu em Moreri, destaca do artigo o que "plus tard, nous retrouverons sous la plume de René Rapin”, ou seja, a crítica à obscuridade dos versos camonianos e a incompreensível simbiose das fábulas pagãs com a religião cristã.

Ao consultarmos uma tradução espanhola do dicionário de Moreri, datada de 1853, verificámos uma notável actualização apreciativa do poeta. Camões é um "excelente Poeta", e, por isso: "es igual en las ideias y expressiones naturales à los dos famosos Poetas de Grecia y Roma, y su unco defecto es su demasiado apego à seguir la Historia de las Indias. Es incomparable en sus demais Poesias". ${ }^{15}$ Como vemos, as anteriores críticas a Camões desapareceram. O poeta até deixou de falecer pouco depois dos cinquenta anos; viveu um pouco mais: "y al cabo de muy dilatada enfermedad murió con dictamenes de gran piedad y dificacion, el año de 1579 à los 70. años de edad". ${ }^{16}$ As duas versões concordam, porém, na atribuição de contornos mítico-lendários à biografia do épico português, como é a imagem deste, sobrevivendo ao naufrágio, no seu regresso às Índias de volta de Macau e da China, segurando na sua mão direita Os Lusíadas e servindo-se da esquerda para nadar, como um César.

Às progressivas valorizações de Camões que as sucesivas edições do dicionário evidenciam, não é inocente a opinião mais justa de Adrien Baillet, exposta em Jugements des çavants sur les principaux ouvrages des auteurs (1685). Apesar de, na linha dos seus

\footnotetext{
${ }^{14}$ cf. COUTINHO, 1941, p.57.

${ }^{15}$ MORERI, 1753, p.94, grifos nossos.

${ }^{16}$ MORERI, 1753, p.93.
} 
predecessores, censurar a mistura do maravilhoso pagão com matéria religiosa, não tem dúvidas sobre o valor do nosso épico:

Le Camoens passe dans le monde pour le Martial, l'Ovide, l'Horace et le Virgile des Portugais. Ce qu'il a fait d'Epigrammes, d'Elégies e d'Odes a été imprimé in- $4^{\mathrm{O}}$ à Lisbonne. On aurait pu le prendre aussi pour le Plaute du pays, s'il suffit d'avoir fait des comédies pour cela.

Mais nous ne le considérons ici que comme un poète héroique et comme le véritable Virgile de sa Nation, à cause de son célèbre poème des Lusiades, ou de la conquête des Indes par les Portugais. ${ }^{17}$

Enquanto que Moreri e Rapin pecaram por diminuir injustamente o valor de Os Lusíadas, A. Baillet, influenciado ele também pela Bibliotheca hispana nova sive Hispanorum scriptorum de Nicolao Antonio $^{18}$, não se coibiu de revelar, num contexto, sublinhe-se, adverso ao poeta, uma exaltação algo exagerada, como confirmam estas quatro encomiásticas apreciações:

Camoens avait un génie tout à fait extraordinaire; il était né poète; il avait l'esprit vif, sublime, net, abondant, aisé et prompt à tout ce qu'il vouloit.

Qu'il réussissait parfaitement dans les matières héroiques \& galantes \& que non seulement les connaisseurs du pays, mais encore le Monde lui ont rendu ce témoignage.

(...) que ce poète avait un talent particulier pour faire les descriptions des lieux des portraits de personnes, \& qu'il y est si juste \& si accompli, que son art égale presque la nature" (grifos nossos).

Ses comparaisons sont riches, ses épisodes fort agréables \& fort diversifiés, quoiqu'ils ne détournent pas le lecteur du sujet principal de son Poème. Il témoigne partout beaucoup d'érudition, mais elle n'est pas affectée: \& l'on trouve qu'il a le goût des Anciens qui est tout le fruit qu'un Poète puisse prétendre de retirer de la connaissance de l'antiquité. ${ }^{19}$

\footnotetext{
${ }^{17}$ BAILLET apud MORERI, p.520.

18 cf. COUTINHO, 1941, p.63-4.

19 apud COUTINHO, 1941, p.64.
} 
Como se lê, Baillet opina de forma eufórica. Não ousamos imaginar em que termos elogiosos trataria Camões se tivesse lido a epopeia. Seja como for, trata-se de um claro sinal de viragem na maneira de ver Os Lusíadas, de apreciar Camões.

De um modo geral, a propósito da recepção de Camões, no contexto seiscentista francês, convocaríamos a, já citada, frase de Xavier Coutinho: "En somme, dès 1640 il faisait son chemin, mais péniblement". E, no entanto, não se pode alegar que a obra fosse desconhecida. Em Portugal, o poema épico teve um sucesso retumbante. Fizeram-se duas edições sucessivas no ano em que foi publicado; duas outras em 1584; uma em 1597; e depois em 1607, 1609, 1612, 1613, 1615, 1633 e 1639. Diríamos que se tratou de um autêntico best-seller (utilizando abusivamente uma expressão de hoje), que não se ficou por cá. A epopeia também foi saboreada, com muito apreço, além fronteiras. Benit Caldera (1580), Luiz Gomez de Tapia (1580) e Henrique Gariez (1591) traduziram-na para júbilo da Espanha; os ingleses leram-no em 1654 pela pena de Fanshaw; e os italianos pela de Carlo Antonio Paggi em 1658. E em França? Nenhuma tradução. Apenas as três referências a Camões que vimos. Duas breves e maldicentes; uma mais demorada e generosa. Como explicar que em Portugal, Espanha, Inglaterra e Itália Camões fosse motivo de recepção entusiasta, e que na França se ficasse por uma rejeição quase assumida? Só uma breve análise histórico-social e cultural do contexto seiscentista nos poderá esclarecer.

Portugal era foco de interesse para ambições expansionistas da francesas. Lisboa representava um importante centro de comunicações com o Extremo Oriente que os mercadores franceses não desprezavam. Possuía, talvez por isso, um inegável prestígio. A língua portuguesa, paralelamente, detinha uma importância semelhante à que o inglês hoje conhece. O nosso idioma afirmavase como passaporte linguístico para as trocas comerciais. E quem desejasse fazer fortuna por terras orientais tinha necessariamente de se submeter à língua de Camões. Do mesmo modo, os missionários franceses recorriam ao português para aprenderem as línguas 
orientais. Mas ao expansionismo do nosso sistema idiomático não lhe correspondia um adequado conhecimento filológico. O Português era tido como uma variante dialectal do Castelhano. A ocupação filipina (1580-1640), por seu turno, não facilitou a demarcação linguística. A utilização do Castelhano por alguns dos nossos letrados e poetas também não terá revelado muita intuição patriótica, acentuando a confusão no espírito francês, decididamente pouco à vontade na diferenciação do Português do Espanhol no campo das letras e das artes. Não se distinguem os poetas portugueses dos de Espanha. A independência restaurada não conseguiu avivar em França a especificidade literária e artística do nosso país. Teorias que, por essa época, pretendiam explicar o "génio" poético mediante factores de ordem climatérica e psíquica reforçarão a identificação entre os dois povos ibéricos: são povos sujeitos a um mesmo clima e com costumes semelhantes. ${ }^{20}$ Porém, o que explica verdadeiramente a recepção parca e extremamente parcial de Os Lusíadas, em França, no século XVII, tem a ver com uma atitude literária bem evidente nos críticos: a da supremacia. A poesia francesa é tida como modelo exemplar a seguir, pois primava pela clareza e equilíbrio dos seus versos. Qualquer manifestação de excesso, de complexidade e obscuridade hermenêutica é, de imediato, irradiada do panorama estético. Os franceses não toleram a falta de inteligibilidade. Desprezam igualmente, por chauvinismo, tudo quanto não seja francês, abrindo uma compreensível excepção para os autores da Antiguidade Clássica que admiram sem, todavia, os copiar com servilismo. Se Camões foi mal recebido, no século XVII, Shakespeare é ignorado! ${ }^{21}$ De nada servirá ao conde de Ericeira traduzir em 1693 a Art Poétique de Boileau. Da sua pena não sairá o nome de Camões. A influência dos "Estrangeirados" também não abriu a Camões as portas de um povo, interessado no nosso país

\footnotetext{
${ }^{20}$ cf. PAGEAUX, 1984a, p.27.

${ }^{21}$ cf. BISMUT, 1981, p.724.
} 
apenas sob uma esfera diplomática e política, como o denunciam as numerosas publicações, em França, de obras de história de Portugal, que de Camões nem o nome referem.

A. Baillet abriu uma brecha na recepção camoniana em França, a partir da qual o poeta passou, progressivamente, a merecer outros olhares, mais benévolos, menos desfazados. Acontecimentos, transcendentes a Baillet, ajudaram também essa gradativa promoção de Os Lusíadas. A política do despotismo esclarecido ou "iluminado" desenvolvida pelo Marquês de Pombal é um deles. A governação pombalina agrada aos franceses, em particular aos filósofos, entre os quais o Marquês granjeia admiradores e partidários. É uma política mais europeia, que afirma o seu vigor na expulsão dos jesuitas, acto inédito num país marcadamente católico como Portugal, que é aplaudido por muitos espíritos anticlericais franceses. A condução pombalina é enérgica, caracteriza-se por importantes reformas administrativas e políticas e serve, por isso, a ideologia, por mais francocentrista que seja, dos letrados e dos filósofos de Paris. Os Enciclopedistas aclamam o homem que libertou Portugal da "fumarada das fogueiras da Inquisição". O novo rumo político do nosso país que, além disso, continua grande potência colonizadora e comerciante começa a seduzir os romancistas da época que elegem Lisboa ou outras cidades do império para situarem a acção diegética dos seus heróis romanescos, como acontece em Candide de Voltaire. $^{22}$

O atentado contra o rei D. José e o trágico tremor de terra de 1755 continuam a despertar a opinião pública francesa para o nosso país. O interesse só não terá sido maior, porque Cadiz, na qual viviam numerosos negociantes franceses e, ainda por cima, o bisneto de Racine, tremeu no mesmo ano. ${ }^{23}$

Determinante na crescente afirmação do nosso poeta, não deixa de ser a crise do contexto literário francês. A razão continua

22 cf. SALOMON, 1928, p.648.

23 cf. PAGEAUX, 1984a, p.33-4. 
a reinar dogmaticamente nas letras, pelo menos até à década de 30, mas o culto da imitação dos antigos não encontra elementos. Voltar a imitar Plauto, Séneca, Sófocles, Horácio...seria por demais redundante. Abusou-se no século anterior dos gregos e dos latinos. Pouco sobrou para o actual. A solução possível só é uma: partir à descoberta de outros povos e outras civilizações. Shakespeare emerge finalmente e, como diz Bismut, "Les nouveaux chemins de la curiosité ouvrent donc tout naturellement les portes du Royaume à Camões et à son épopée”. ${ }^{24}$

E um dos primeiros a entreabrir a porta é Voltaire. Não se pode afirmar que o filósofo desconhecesse Portugal. Ele assinala em Essai sur les moeurs, Le siècle de Louis XIV, Dictionnaire philosophique e outras obras, alguns factos pontuais da história de Portugal, que vai buscar a La Clède e ao abade Vertot. Isso não o impede de partilhar “(...) os preconceitos da sua época, confundindo muitas vezes Espanha e Portugal e atribuindo à inquisição um papel fora de proporções com a sua importância". Nada de mais natural numa mente devorada por uma suprema finalidade : “(..) prosseguir na sua propaganda filosófica contra os monarcas absolutos e contra a Igreja". ${ }^{25}$ Posicionou-se, no entanto, perante a epopeia de Camões, de forma encomiástica.

Foi durante o seu exílio em Inglaterra que surgiu, em 1727, Essai on Epickpoetry, no qual "Le Camoens" é esteticamente avaliado pelo filósofo ao lado de outros grandes épicos europeus como Ercilla e, claro, ou não estivesse Voltaire em Inglaterra, Milton. Esta obra, traduzida pelo Abade Desfontaines, por ser a primeira do género épico a buscar exemplos na literatura moderna, foi editada um pouco por toda a Europa em várias edições. Voltaire, apesar da leitura e da apreciação parcial que fez de Os Lusíadas, como confessa a M. de Vannes, confere-lhe um importante destaque. Já não é Rapin quem avalia: "L'obscurité du Camoens fait tout son

${ }^{24}$ BISMUT, 1981, p. 725.

25 cf. SALOMON, 1928, p.649. 
mérite; Les Portugais l'admirent d'autant plus qu'ils l'entendent moins. Il a bien exprimé la fierté de sa nation". ${ }^{26}$

Mas a mistura do maravilhoso pagão com o maravilhoso cristão é um fantasma que continua a merecer reparo. Voltaire não perdoa a Vénus o atendimento à súplica de Vasco da Gama; a coerência impunha uma acção divina, que o navegador, como verdadeiro cristão, solicitou e não uma incongruente interferência pagã:

On ne sera plus autant surpris que Gama, dans une tempête, adresse ses prières à Jésus-Christ, et que ce soit Vénus qui vienne à son secours... A parler plus sérieusement, un merveilleux si absurde défigure tout l'ouvrage aux yeux des lecteurs sensés... ${ }^{27}$

E os dogmas do século XVII ainda têm voz nas reprovações que Voltaire faz a Os Lusíadas: “(...) de tous les défauts de ce poème, le plus grand est le peu de liaison qui règne dans ses parties; il ressemble au voyage dont il est le sujet". ${ }^{28}$

Além disso: "Son poème de la découverte des Indes, qu'il intitula Lusiade; titre qui a peu de rapport au sujet et qui, à proprement parler, signifie La Portugade". ${ }^{29}$

Com estes aspectos "pitoyables" a sentença adivinha-se: "A la vérité Camoens a beaucoup d'esprit; mais il en a aussi en même temps de ce qu'on appelle le faux esprit; il le possède dans un degré qui n'est pas médiocre: ce qui le précipite dans les plus énormes absurdités". ${ }^{30}$

De forma contrapolar, Voltaire consente à elevação de Camões, a propósito do episódio inesiano: "C'est à mon gré le plus beau morceau du Camoens, il y a peu d'endroits dans Virgile plus attendrissants et mieux écrits". ${ }^{31}$

\footnotetext{
${ }^{26}$ VOLTAIRE apud COUTINHO, 1982, p.552.

${ }^{27}$ apud BAR, 1980, p.653.

28 apud BAR, 1980, p.652.

29 apud BAR, 1980, p.651.

30 apud BISMUT, 1981, p.733.

31 apud BAR, 1980 , p.653.
} 
Do Adamastor dir-nos-á o iluminista: "Cela est grand en tout pays, sans doute". ${ }^{32}$

Pouco a pouco o crítico cai em si e reconhece um Camões que: "S'acquérait une réputation qui dure encore parmi ses compatriotes, qui l'appellent le Virgile Portugais". ${ }^{33}$

Se o poeta supõe defeitos, também nele se localizam, em contrapartida, inegáveis qualidades:

Le poète n'a d'autre art que celui de bien conter les détails, mais cet art seul, par le plaisir qu'il donne, tient quelquefois lieu de tous les autres. Tout cela prouve enfin que l'ouvrage est plein de grandes beautés, puisque depuis deux cents ans il fait les délices d'une nation spirituelle qui doit en connaître les fautes. ${ }^{34}$

O exigente avaliador acaba por se converter em fervoroso admirador da genialidade do épico português - Camões transita para a condição de percursor: "Le Camões, en Portugal, ouvrait une carrière toute nouvelle..."35 "La simplicité du poème est rehaussé par des fictions aussi neuves que le sujet." 36 Os Lusíadas deixam de ser uma epopeia equivalente a outras; são antes um exemplo da "L'épopée philosophique"37

Le sujet de La Lusiade, traité par un esprit aussi vif que le Camoens, ne pouvait que produire une nouvelle espèce d'épopée. Le fond de son poème n'est ni une guerre, ni une querelle de héros, ni le monde en armes pour une femme: c'est un nouveau pays découvert à l'aide de la navigation. ${ }^{38}$

32 apud BAR, 1980 , p.653.

33 apud BAR, 1980 , p.654.

34 apud BAR, 1980 , p.654.

35 apud BAR, 1980 , p.653.

36 apud BAR, 1980 , p.654.

37 cf. BISMUT, 1981, p.732.

38 apud BAR, 1980, p.653. 
Voltaire rende-se perante o génio de Camões. Elogia-o magistralmente, comparando-o a Homero: "Ainsi il éprouva en tout le sort d'Homère. Il voyagea comme lui; il vécut et mourut pauvre, et n'eut de réputation qu'après sa mort" ${ }^{39}$

Não surpreende que Camões interferisse no universo criativo do filósofo - se Voltaire não apreciasse devidamente o poeta, certamente La ligue ou Henri le Grand (1723) não passaria a la Henriade por influência de Os Lusiadas. ${ }^{40}$

A análise de Voltaire é seguramente de grande relevância para Camões. Por um lado, trata-se do veredicto estético de alguém que terá contactado com a epopeia, embora por via de tradução. É, por essa razão, uma análise e não uma mera referência iterativa, dependente de juízos tendenciosos, como no caso de Moreri e R. Rapin. Registe-se, por outro lado, que a dimensão do nome de Voltaire, alienará, de um modo geral, as valorações de Camões que seguirão as do Essai sur le poème épique. O abade Prévost é exemplo dessa alienação ao adoptar uma perspectiva semelhante à do filósofo, relativamente à concepção do maravilhoso n'Os Lusíadas defendida em le Pour et Contre (1735).

Os defeitos que Voltaire aponta a Camões acusam, em nossa opinião, frustração. Muitos são os poetas franceses que sonham obsessivamente em criar uma gloriosa epopeia que marcasse as letras desse país, habituado a ditar os cânones estéticos. Já lá vai o tempo da Franciade de Ronsard e de algumas epopeias falhadas como a Pucelle de Chapelain. Voltaire compõe La Ligue, mas fica aquém do pretendido. Admitir a superioridade portuguesa no épico equivale a admitir a inferioridade francesa nesse género.

A impossibilidade, porém, de negar a grandeza incontestável de Os Lusíadas, sob pena de parcialidade crítica que a história não esqueceria, só conduz a uma solução: reconhecer o mérito, mas denunciar a todo o custo qualquer desrespeito às dogmáticas normas

39 apud BAR, 1980, p.654.

${ }^{40}$ cf. COUTINHO, 1982, p.521. 
do século XVII francês. Foi o que Voltaire fez, sujeitando-se, por isso, também ele, a duras críticas. Outros críticos se seguem.

O abade Desfontaines, amigo e admirador de Voltaire, no seu livro Observations sur les écrits modernes (1735), mostra, tal como o abade Prévost, ter lido e meditado com muito empenho e fidelidade o Essai sur la poésie épique, de tal modo que a primeira tradução de Os Lusíadas (1735) de Duperron de Castéra não convenceu o clérigo de alguns erros críticos que o seu mestre, apesar de ilustre filósofo iluminista, cometera:

Je ne suis pas surpris, Monsieur, que les Portugais aient voué leur admiration à La Lusíade du Camoens, et qu'ils la comparent à l'Iliade. Leur propre gloire y est intéressée. Il faut pourtant convenir qu'il y a de grandes beautés dans ce poème. L'auteur dédaignant de marcher sur les pas d' Homère et de Virgile, s'est ouvert une route nouvelle: il a choisi un sujet fort simple, je veux dire la découverte des Indes Orientales par les Portugais, et il l'a orné de fictions neuves et hardies. Vasco da Gama, le chef de ces nouveaux Argonautes, dont le Camoens partagera les périls et la gloire, est le héros du poème, et c'est sur lui que rejaillit l'honneur de cette célèbre expédition. Ce poète est un peintre hardi, d'une imagination souple et féconde, qui se plie avec un succès égale au sublime, au simple et au gracieux, et qui manie les passions avec beaucoup de forces et de délicatesse: ses descriptions sont neuves et vraies; il peint les lieux, les moeurs et les personnes qu'il a connues dans ces pays éloignés. (... $)^{41}$

Desfontaines comete o mesmo erro de Voltaire ao acreditar que Camões participara na expedição de Vasco da Gama, a qual, na realidade, se realizara, pelo menos, vinte e cinco anos antes do nascimento do grande poeta. Esta imprecisão não o desobriga, todavia, de repreender ironicamente Duperron de Castera: "Jupiter, selon le traducteur, est Dieu le Père, Bacchus le Démon, Vénus la Religion chrétienne, Mars Jésus-Christ, Mercure un ange, Cupidon le Saint-Esprit, etc.. (...)" ${ }^{42}$

${ }^{41}$ apud BISMUT, 1981, p.730, grifos nossos.

42 apud BISMUT, 1981, p.730. 
Juvenal de Carlencas em Essais sur l'histoire des belles lettres des sciences et des arts (1747) regressa, nostalgicamente, à era do "Père Rapin” ao retomar, por vezes textualmente, certos propósitos do jesuíta.

A crítica que Racine expõe na sua obra Réflexions sur la Poésie (1747) é mais progressista, segue as pisadas de Voltaire e Desfontaines, reprovando, como já é tradição, a harmonização de figuras pagãs com cristãs; e nem a "Ilha dos Amores" o remove de seguir a tradição:

On tâche d'excuser les Poètes paiens en donnant à leurs fictions extraordinaire le nom d'allégories; mais peut-on excuser de même nos Poètes? L'allégorie de la Jérusalém Délivrée, quoiqu'expliquée par le Tasse lui-même est ridicule. Les défenseurs du Camoens ont beau nous dire que, par Vénus qui protège les Portugais, il faut entendre la religion chrétienne, qu'ils doivent établir dans les Indes, et que Bacchus, leur ennemi, est le Démon, ce sérieux de l'explication ne sauve pas l'extravagance de la fiction. C'est par une allégorie également absurde qu'ils veulent expliquer cette île enchantée et plus voluptueuse que le palais d'Armide, où se fait l'union des Portugais avec les Néréides. On ne peint point la vertu sous les couleurs du vice. ${ }^{43}$

Esta crítica não invalida Racine de, num artigo intitulado la Fortune des Poètes, celebrar um elogio implícito a Camões, ao comparar o Virgílio de Portugal a Tasso:

(...) le Tasse ne trouva point dans cette même maison d'Este de plus solides protecteurs. Il était si pauvre, que dans un de ses sonnets il priait sa chatte de lui prêter la lumière de ses yeux pour écrire pendant la nuit, n'ayant pas de quoi acheter une chandelle. La fortune du Virgile du Portugal a été encore plus cruelle, que celle du Virgile de la moderne Italie, puisque le Camoens mourut dans un hôpital. ${ }^{44}$

Montesquieu (1748), ser de muita prudência, guarda-se de julgar negativamente um génio, que sabe estar à altura de Virgílio e Homero.

43 apud BISMUT, 1981, p.731.

${ }^{44}$ apud COUTINHO, 1982, p.523; grifos nossos. 
Les Portugais, navigant sur l'océan Atlantique, découvrirent la pointe la plus méridionale de l'Afrique; ils virent une vaste mer; elle les porta aux Indes orientales. Les périls sur cette mer, et la découverte de Mozambique, de Mélinde et de Calicut, ont été chantés par le Camoens, dont le poème fait sentir quelque chose des charmes de l'Odyssée et de la magnificence de l'Enéide. ${ }^{45}$

E Diderot numa carta datada de 1774 estabelece uma curiosa hierarquia, digna de menção: "Si je préfère Homère à Virgile, Virgile au Tasse, le Tasse à Milton, Milton à Voltaire ou au Camoens, ce n'est point une affaire de dates" 46

Todos estes comentários sobre Camões e Os Lusíadas reflectem um crescente interesse da crítica pela epopeia do Virgílio de Portugal no século XVIII. Camões conquistou presença efectiva em manuais, volumosos tratados, dicionários e um lugar cativo na Encyclopédie. E se as numerosas referências a Camões se inspiram, em geral, na de Voltaire e realçam aspectos da concretude existencial do poeta, nem sempre reais, sobretudo no que concerne às desgraças deste, admiradas ao ponto de ofuscarem a própria obra e de não contribuírem para um íntimo conhecimento desta, a verdade é que delas decorreu um enorme prestígio para Camões.

\section{Traduções, imitações, versões}

O estudo da temática das traduções de Os Lusíadas em França inicia-se com um enigma, digno de Sherlock Holmes, ainda hoje não resolvido. Baillet é o autor do mistério quando em 1685 no seu Jugement des çavans escreve, a propósito da tradução da epopeia "On le mit en Français il y a environ cent ans". ${ }^{47}$

\footnotetext{
${ }^{45}$ MONTESQUIEU, 1973 , p.58; grifos nossos.

${ }^{46}$ apud PAGEAUX, 1984b, p.225; grifos nossos.

${ }^{47}$ apud COUTINHO, 1941, p.67.
} 
Esta afirmação simples e concisa pressupõe que Os Lusiadas tenham sido traduzidos entre 1584 e 1600. Onde se encontra essa versão? Quem é o seu autor? Cento e cinquenta anos separam a afirmação de Baillet da realidade: a primeira tradução conhecida data de 1735. É uma tradução completa, tal como será a de La Harpe (1776). Antes de Duperron de Castéra apenas encontramos o tratamento de temas camonianos, como o episódio de "Inês de Castro" que seduzira B. de Brillac em 1688, La Motte em 1723 e em 1724 Desfontaines; mas nenhuma tradução de Os Lusíadas desperta no horizonte. A polémica frase de Baillet estaria, assim, votada a um fácil esquecimento se não fosse a curiosa insistência na fantasmagórica tradução. Bem antes do crítico francês, em Portugal, o jesuita Mateus Cardoso, nos inícios do século XVII, escrevera: "Hunc Itali, Galli, Hispani vertere Poetam". ${ }^{48}$

Noutro epitáfio, em honra de Camões, surge também a ideia de uma tradução francesa antiga: "Quis etiam variis modulatur liguis Italo et Hispano, gallico et ore sonnat". ${ }^{49}$

Domingos Fernandes, na sua dedicatória, ao arcebispo Rodrigo da Cunha, da sua edição de 1609, evoca novamente a tradução. O mesmo se passará com a edição de 1613 de Pedro de Mariz.

Nicolau António, que viría a ser ponto de refência obrigatório para a crítica camoniana, alude ao sucesso da epopeia que teria sido acolhida em vários países, entre os quais a França por várias versões:

lusitano in peregrinas líguas conversionibus (...) Hujus Poematis interpretationem latinam dedit Thomas de Faria (1622)..., Gallicam alius! Italicam, cum ille anonymus cujus Petrus de Mariz proxime laudandus meminit tum Carolus Paggius Genuensis Alexandro VI..., typis anno 1665 Olissipone edidit cum vitae authoris eleganti compendio. ${ }^{50}$

\footnotetext{
48 apud COUTINHO, 1941, p.69.

49 apud COUTINHO, 1941, p.69, grifos nossos.

${ }^{50}$ apud COUTINHO, 1941, p.70.
} 
A ideia de uma tradução francesa antiga continua ganhando contornos, quando, em 1776, um senhor de nome Buisson, em Voyage du ci-devant Duc du Chatelet en Portugal, afirma: "Camoens est un des poètes étrangers qui a été le plus célébré en France. Sa Lusiade a été traduite trois fois". ${ }^{51}$

A ideia viria, todavia, a perder fôlego pela feliz nacionalidade do abade Goujet que lembrou, em Bibliothèque française ou Histoire littéraire de la France (1755), o óbvio: "Que personne ne connait, \& qui peut-être n'a jamais été imprimé, s'il est vrai même qu'elle ait existé". ${ }^{2}$

De facto, ninguém parece ter visto a tradução. Por esse motivo, de nada serviriam as buscas do padre Macedo (1641-2). E de muito menos serviu atribuir à hipotética tradução os hipotéticos autores Scarron, Simon Goulart Senlisien e Jean Nicot, ${ }^{53}$ a não ser, no caso deste último, no sentido de aligeirar o peso da nicotina que introduzira em França pela leveza da epopeia que poderia ter introduzido.

Surge, então, em 1735, e com um substancial atraso face a outros países europeus, a primeira tradução de Os Lusíadas, intitulada "la Lusiade de Camoens, poème héroique sur la découverte des Indes orientales". O seu autor, diplomata de carreira, é LouisAdrien Du Perron de Castéra. Esta tradução "en prose, mais en prose poétique et nombreuse" é comercializada nas livrarias de Huart, David, Clousier et Briasson. Apesar de defeituosa em alguns aspectos de compreensão textual, o seu valor é meritório. Duperron de Castera, como assinala Daniel-Henri Pageaux ${ }^{54}$, "a, dans l'ensemble, compris les intentions de Camoens: banalité qui n'en est pas une pour un siècle qui voit des traducteurs bien hardis ou bien

\footnotetext{
${ }^{51}$ apud COUTINHO, 1941, p.68.

52 apud COUTINHO, 1941, p.71, grifos nossos.

53 cf. COUTINHO, 1941, p.67-72.

${ }^{54}$ PAGEAUX, 1984b, p.198.
} 
désinvoltés". Na introdução, o tradutor realça os aspectos técnicoformais que passaram, até então, despercebidos:

le sujet en est grand et tel qu'il le faut pour l'épopée; c'est la découverte des Indes par les Portuguais; l'unité de la principale action et celle du héros s' y trouvent observées parfaitement; on y voit une conduite ménagée avec art, une allégorie sublime, plusieurs épisodes bien amenés (...) enfin un style varié suivant l'éxigence des matières. ${ }^{55}$

O erro magno de Castéra foi pretender impor uma leitura de Camões mediante um conjunto de regras, um organon de princípios que facilitasse a compreensão da epopeia: Baco é o diabo; Vénus, a religião; Marte, Jesus-Cristo, etc. Desta generosa pretensão, além de despertar acesas polémicas com Voltaire e o abade Prévost, resultou um entendimento mais obscuro e complexo do poema.

Esta primeira tradução de Os Lusíadas, na esteira de Faria e Sousa, é de extrema importância, pois que não só ofereceu finalmente aos franceses, por mais defeituosa que possa ter sido, a epopeia que a crítica desde 1698 referia, como insurge-se clara contestatária das opiniões de Voltaire e seus seguidores que se começam a sedimentar junto da crítica.

No ano de 1776, a França é brindada com uma nova tradução, resultante da colaboração de dois letrados: Vaquette d'Hermilly, tradutor de Montiano e Quevedo entre outros e Jean-François de La Harpe, conhecido nos meios literários franceses após ter ganho o primeiro prémio de poesia da Academia Francesa com um poema intitulado Navigation, de estreita influência camoniana.

O prefácio desta nova edição é expectante:

Cette nouvelle traduction de Camoens, dont on peut en général garantir la fidélité, est l'ouvrage d'un écrivain très connu; elle a été faite sur une version littérale du texte portugais, version composée avec tout le soin et l'exactitude possible par un homme versé dans la langue de Camoens. ${ }^{56}$

\footnotetext{
${ }^{55}$ apud PAGEAUX, 1984b, p.198.

56 apud GENTIL, 1986, p.184.
} 
Isso não impede de o bom senso de La Harpe, movido, com certeza, pela vontade de lutar contra a "paraphrase froidement empoulée et prolixement périodique" do seu predecessor, de "animer du feu de la poésie cette version scrupuleusement fidèle". E como o faz este engenhoso tradutor? Simplesmente utilizando a arte de "resserer les endroits un peu longs"! ${ }^{77}$ Não admira, portanto, que Roger Bismut comente a edição de 1776 nestes termos: "Depuis que les critères de la traduction ont évolué, on peut, on doit même rejeter ce type de traduction qui ne mérite pas même le qualificatif de belle infidèle, car si elle est infidèle sa valeur esthétique est pauvre". 58

Ao contrário de Castéra, muito criticado nesta segunda tradução, La Harpe demonstra muita pouca afeição literária pela obra de Camões: "Il n'y a ni d'assez grands dangers ni de situations assez attachantes, ni de personnages assez héroiques pour former la fable d'un poème". ${ }^{59}$ E nas suas escassas valorizações do poeta português, segue incondicionalmente Voltaire: "Quelques morceaux frappants épars dans la Lusiade, tels que l'apparition du génie de l'océan près du cap de Bonne-Espérance et l'épisode d'Inès surtout: des détails heureux semés dans tous les chants de son poème, voilà ses titres à la postériorité". ${ }^{60}$

Uma pergunta impõe-se: porque razão terá La Harpe empreendido uma co-tradução de Os Lusiadas, não apreciando a sua obra nem mesmo o seu autor? A tentativa de La Harpe e de Hermilly pode enquadrar-se no interesse que as literaturas ibéricas começaram timidamente a despertar, nesse período, para alguns letrados franceses, motivados pela renovação de conhecimentos literários, gastos pelo século XIX. Numa perspectiva mais íntima, é

\footnotetext{
57 apud GENTIL, 1986, p.184.

${ }^{58}$ BISMUT, 1981, p.725.

59 apud GENTIL, 1986, p.184.

${ }^{60}$ apud GENTIL, 1986, p.184.
} 
l'Année Littéraire, para a qual La Harpe "dépouille d'une main et poignarde de l'autre" ${ }^{\prime 61}$ que parece fornecer uma adequada resposta: "Mais si la Lusiade n'est qu'une production médiocre, comment M. de La Harpe a-t-il pu prostituer sa plume à la traduire?" (...) "Faire adroitement sa cour à M. Voltaire". ${ }^{62}$

Roger Bismut, num artigo intitulado Camões en Procès sous la terreur $^{63}$ assinala a existência de uma terceira tradução, anterior ao século XIX, que vem assim preencher o vazio de cinquenta anos entre a de La Harpe e a de Millié (1825). Esta tradução, encontrada no Rio de Janeiro, não é nem datada nem assinada. O tradutor teve, porém, o invulgar cuidado de colocar em frente do texto francês o português. Bismut sugere como datas limites de composição do manuscrito 1794 e 1798. Esta datação apoia-se em quatro factos: (i) a grafia é do século XIX; (ii) o tradutor anónimo (A.), ao referir-se a La Harpe, utiliza a designação de Citoyen, perfeitamente adequada a um polígrafo que leccionara na Universidade de Paris no período robespierrista da Revolução; (iii) fala-se na tradução em Bibliothèque Nationale, ora nos últimos anos do reinado de Luís XIV, essa instituição tinha o óbvio nome de Bibliothèque Royale, depois de 1805, designou-se Bibliothèque Impériale; (iv) o A. relega para a condição de notas trechos (a instância 45 e os 4 primeiros versos da 46 do Canto III; a estância 35 do CantoV; e as estâncias 109-118 do Canto X), por motivações político-ideológicas dignas do jacobinismo. A justificação para tal procedimento é de um absurdo incrível:

Mais je vais plus loin, et, dût-on m'accuser d'enthousiasme et de partialité, j'ai de fortes raisons de croire que l'Inquisition a ajouté, ou fait ajouter au poème du Camoens Après sa mort, plusieurs strophes qu'il n'avait pas composées. J'en citerai par exemple les Octaves 82, 83, 84 et 85 du dixième chant. ${ }^{64}$

\footnotetext{
${ }^{61}$ PAGEAUX, 1981, p.201.

62 PAGEAUX, 1981, p.201.

63 cf. BISMUT, 1983, p.251-3.

${ }^{64}$ apud BISMUT, 1983, p.253, grifos nossos.
} 
Sobre Duperron, o nosso A. teve o desplante de afirmar: “...Il a tronqué et défiguré l'original, fait des omissions considérables, et mis souvent son esprit à la place de celui du Camoens, qui est loin de gagner à cette substitution (...)" ${ }^{65}$ Curiosas censuras para quem, com tanta liberdade, desfigurou parte de Os Lusíadas. Foi bem mais elogioso para La Harpe, ou não fosse este Citoyen!

La seconde traduction qui parut en 1776, est du C(itoyen) La Harpe, et l'emporte autant sur celle de son prédécesseur que la Phèdre de Racine sur celle de Pradon; elle est digne de l'original par l'élégance du style ${ }^{66}$

A tradução deste A., embebido de propósitos jacobinistas, apesar de revolucionária, marca, contudo, uma evolução face às duas tentativas anteriores, e até à de Millié. A despeito de "por vezes (...) ser estritamente fiel ao original", consegue, em variados aspectos, furtar-se ao "nebuloso" da de La Harpe sem cair "no grau satisfatório de exactidão" nem sempre atingido por Millié. ${ }^{67}$

Paralelamente às traduções, aparecem, ao longo do século XVIII, versões, dadas como traduções ou imitações, que se destacam pelo acréscimo de elementos, ao sabor da sensibilidade autoral. Assim, em 1772 é publicado na Bélgica um opúsculo, reeditado no ano seguinte, intitulado Essai d'imitation de l'épisode d'Inès de Castro dans le poème des Luziades de Camoens, posto à venda em Bruxelas por J. Vanden Berghen. Esta imitação é famosa pela especulação que gerou em torno da identidade da sua autora que apenas se deu a conhecer sob a forma misteriosa de M.elle M. M.. A hipótese, agora ultrapassada, de se tratar de M.elle Jeanne-Marie Bouvière de La Motte Guyon foi levantada por B. Xavier Coutinho, ${ }^{68}$ que alegou motivos de natureza cronológica e tipográfica. António Coimbra Martins ${ }^{69}$ identifica-a como sendo Rose

\footnotetext{
${ }^{65}$ apud BISMUT, 1982, p.63.

${ }^{66}$ apud BISMUT, 1982, p.63.

${ }^{67}$ cf. BISMUT, 1982, p.63-4.

${ }^{68}$ cf. COUTINHO, 1941, p.35-47.

${ }^{69}$ MARTINS, 1981, p.99.
} 
Murray (1741-1831), conhecida como Muse Bélgique. O interesse pelo episódio camoniano terá sido despertado pelo conde D. José Vasques, Ministro Plenipotenciário de Haia entre 1766 e 1776, com o qual manteve uma relação amorosa e pelo qual terá descoberto a beleza de Os Lusíadas. António Coimbra Martins localiza em Moscovo um dos exemplares raríssimos do Essai d'imitation .... ${ }^{70}$ Esta imitação em verso é constituída por 153 versos alexandrinos divididos em 14 estrofes desiguais. Afasta-se do original em vários pontos, mas como a autora teve o cuidado de lhe chamar "imitation livre", fica imune a censuras, que lhe poderiam com pertinência apontar o verso 112 do XII Canto: "Ses bras meurtris d'une chaîne pésante". ${ }^{71} \mathrm{Ou}$, então, o acompanhamento da cena da coroação por uma nota explicativa dos seguintes versos:

Qu'importe, hélas qu'au fond de son tombeau

L'amour lui préparait un triomphe nouveau,

Quand par son triste époux placé au rang sprême

Son front défiguré fut ceint du Diadème. ${ }^{72}$

No dia 6 de Junho do mesmo ano, o major Sulpice Gaubier de Barrault apresentou, em honra do aniversariante D. José I, La Mort d'Inès de Castro et Adamastor, saída de "l'Imprimerie de Lisbonne". O major realça, na sua dedicatória, o universalismo do idioma francês, poderoso meio de difusão:

Camoens, l'immortel Camoens, ira sous les auspices de VOTRE MAJESTE, étendre dans tout l'Univers sa renommée et celle de ses compatriotes, à l'aide d'une langue presqu'universellement consacrée aujourd'hui à transmettre à la postériorité les chefs d'oeuvres de littérature en tout genre. ${ }^{73}$

${ }^{70}$ MARTINS, 1981, p.399.

${ }^{71}$ apud COUTINHO, 1941, p.45.

72 apud COUTINHO, 1941, p.44.

73 apud ROIG, 1983, p.271. 
Passados dezasseis anos, é publicada a obra Mélanges de Poésie et de Littérature, com o subtítulo: "Imitations et traductions". As numerosas reedições desta obra, nos finais do século XVIII e ao longo do XIX, fazem dela um marco relevante na camonologia francesa. O seu autor, Claris Florian, filho de uma espanhola, escreve no seu final:

On s'est attaché dans tout ce morceau à être de la plus scrupuleuse fidélité, et cette attention, qui ne peut être sentie que par ceux qui savent le portugais, les rendra peut-être plus indulgents sur les défauts de cette traduction, surtout s'ils veulent considérer qu'à la dificulté extrême de traduire en vers l'inimitable Camoens, s'est jointe celle de le rendre octave par octave, et presque par vers. ${ }^{74}$

A evolução da sensibilidade estética para com Camões, neste fim de século XVIII, é visível. Gradativamente, dissolvem-se os propósitos pouco abonatórios de Voltaire que ainda terão eco junto de alguma gente, como, no século seguinte, Esménard. No entanto, reconhecese, finalmente, o valor único de Camões, o da sua genialidade.

As traduções integrais e as versões de episódios de Os Lusíadas que se fizeram, no século XIX, nunca se colocaram à altura do original. Pierre Houcarde, no prefácio da tradução de Roger Bismut , sintetiza bem o valor que elas assumem: "Ce qui m'inquiète dans le cas des "Lusiades", c'est la relative rareté des traductions, et le profond discrédit où elles sont vite tombées (...). Aucune, en vers ou en prose, "belle infidèle" ou version docile, n'a mérité vraiment de passer à la postérité". ${ }^{75}$

A explicação da falta de qualidade que as diferentes traduções denotam, pode radicar, utilizando palavras de Ortega y Gasset, na sensibilidade vital do século XVII, cada vez mais vocacionada para a compreensão dos mistérios do homem e do mundo do que para penetrar na inteligência de Os Lusíadas. Os preconceitos estéticos,

\footnotetext{
${ }^{74}$ apud ROIG, 1983, p.271, grifos nossos.

${ }^{75}$ Apud BISMUT, 1954, p.7.
} 
oriundos do jansenismo não ajudaram a entender um maravilhoso pagão de mãos dadas com um maravilhoso cristão ou a dúbia mistura de realismo pitoresco com reminiscências da Antiguidade. O século XVII não acolheu, assim, Camões à luz do seu génio. Os franceses não têm necessidade nenhuma da epopeia moderna, basta-lhes a segura Odisseia:

(...) il n'est pour notre tradition classique d'épopée valable que celle dont on se nourrit sur les bancs du collège. De cette compromission scolaire, le genre n'a jamais pu se relever tant que les lois de l'opinion ont été dictées par une minorité formée à l'humanisme latinisant. ${ }^{76}$

\section{4. À sombra de Camões e de Os Lusíadas}

Luiz Vaz de Camões e a sua epopeia, que lhe rasgou espaços nunca antes navegados por uma obra lusitana, foram até ao século XVIII uma fonte de inspiração para os letrados franceses, mantendo, de resto, ainda hoje, esses estatuto fertilizante, avaliável nas obras encetadas por leituras de Os Lusíadas. A sedutora e idílica "Ilha dos Amores", o arrastante e temível "Adamastor", o trágico e apaixonante episódio de "Inês de Castro" despertaram inspiração/criatividade em escritores, que pelos seus versos e prosa, elevaram um pouco mais o nome de Camões na sensibilidade literária da cultura francesa.

Um dos primeiros letrados a descobrir o valor modelar de certos episódios de Os Lusíadas, nomeadamente os que a crítica já consagrara, foi o abade Jean de Roussy em Aurélia ou Orléans délivré (1738), poema heróico, no qual se alude ao Cabo das Tormentas. ${ }^{77}$ Mme du Bocage, em Colombiade ou la Foi portée au Nouveau Monde (1756), não se esquece da epopeia portuguesa, retratando as conquistas da Espanha, como comprova o Canto X:

${ }^{76}$ HOURCADE apud BISMUT, 1954, p.7.

77 cf. PAGEAUX, 1984b, p.202. 
Bientôt un Lusitain né pour braver les eaux

S'y frayant une route au midi de l'afrique

Deviendra le héros d'un fameux chantre épique. ${ }^{78}$

La Harpe, que tão cruel foi para Camões, curiosamente não se imunizou ao contágio estético da epopeia lusitana. A desvalorização crítica do poeta português foi-lhe inversamente proporcional ao aproveitamento literário que dele fez numa ode intitulada $L a$ Navigation, com a qual ganhou o primeiro prémio da Academia Francesa em 1773. Se o crítico La Harpe evoca Camões para o desprestigiar, o poeta La Harpe evoca-o para o homenagear!

Hélas! Il présageait les maux qui nous punissent,

Ce Chantre renommé, que les Muses chérissent, qui Gama jádis célébra les travaux...

Muse, interromps tes chants, écoute et rends hommage

Au Virgile du Tage:

c'est à lui de chanter les Dieux et les Héros. ${ }^{79}$

O reconhecimento do valor de Camões vai ao ponto de La Harpe imitar o episódio de "O Adamastor":

Ce hardi Portugais, Gama, dont le courage

D’un nouvel Océan nous ouvrit le passage,

De l'Afrique déjà voyait fuir les rochers;

Un fantôme, du sein de ces Mers inconnues,

S'élevant jusqu'aux nues,

D'un prodige sinistre effraya les Rochers ${ }^{80}$

É o vozeirão tonitruente e profético do nosso "Adamastor" que lembramos ao ler estes versos ameaçadores:

\footnotetext{
${ }^{78}$ apud PAGEAUX, 1984b, p.202.

${ }^{79}$ apud COUTINHO, 1982, p.528.

80 apud COUTINHO, 1982, p.528.
} 
Arrête, disait-il, arrête, peuple impie,

Reconnais de ces bords le souverain Génie,

Le Dieu de l'Océan dont tu roules les flots,

Crois-tu qu'impunément, ô race sacrilège!

Ta fureur qui m'assiège

Ait sillonné ces Mers qu'ignoraient tes vaisseaux? ${ }^{81}$

O fantasma, depois de alertar os temerários navegadores das desgraças que os esperam, desaparece à maneira do "Adamastor":

Il dit, et se courbant sur les eaux écumantes,

Il se plongea soudain dans ces roches bruyantes,

Où le flot va se perdre, et mugit renfermé,

L'air parut s'embrasser, et le roc se dissoudre,

Éclatèrent trois fois sur l'écueil enflammé ${ }^{82}$

A navegação dos portugueses até à Índia também fascinou a imaginação de Gré que, em 1781, publicou Navigation, com uma breve alusão a Os Lusíadas. ${ }^{83}$

No entanto, o episódio camoniano que mais sensibilizou os letrados foi o de Inés de Castro. O drama passional de Inês e D. Pedro comoveu e emocionou poetas e escritores, o que se reflectiu em França (e um pouco por toda a Europa) no surgimento, ao longo dos séculos, de romances, novelas, dramas, tragédias, melodramas, etc., a maior parte dos quais de qualidade duvidosa ou simplesmente medíocre. O que motivou o empenho literário de tanta gente a convergir em torno de Inês e da sua tragédia amorosa parece ser a dimensão mítica desta lendária figura feminina. Inês oferece à cultura e à mentalidade francesas uma dimensão passional levada a um extremo que a França não conhece e que, por isso, a cativa e fascina. O sucesso de Romeu e Julieta e de Amor de Perdição assenta numa base explicativa semelhante - que a literatura kitsch contemporânea de teor "cor-de-rosa" trivializou e transfigurou. O tema de Inês de

\footnotetext{
${ }^{81}$ apud COUTINHO, 1982, p.528.

82 apud COUTINHO, 1982, p.528.

${ }^{83}$ cf. PAGEAUX, 1984b, p.202.
} 
Castro foi inaugurado, banalmente, por uma senhora: Mlle de Brilhac (1698) em Agnès de Castro, nouvelle portugaise sem a tutela ainda de Camões.

O mesmo se não passará com Berthes de Bourniseaux, que aproveitará do episódio camoniano, entretanto traduzido, o tom lírico e o eco de alguns versos. Dom Pèdre à Dona Ignez de Castro, héroide é um longo e doloroso monólogo de D. Pedro, inconsolável com a morte de Inês, cuja visão o perturba. Nesta versão de 1788, o príncipe pede misericórdia ao pai e Inês morre pela espada dos cortesãos "indignados" com a clemência de Afonso IV. ${ }^{84}$ "O poema de Berthes de Bourniseaux", nas palavras de M. Leonor Machado de Sousa, ${ }^{85}$ "é a mais completa expressão lírica em francês do episódio inesiano".

A encantatória Ilha dos Amores, versejada por Camões, também mereceu atenções literárias. Em Voyages Imaginaires, Visions et Romans Cabalistiques (1788), passou, por via da adaptação literária, a L'Ile enchantée. Esta adaptação é precedida de um aviso:

Nous allons les promener (nos lecteurs) dans celui-ci (ce volume), premièrement dans une île enchantée, séjour des plaisirs et de la volupté, où Vénus arrête quelque temps Gama et ses compagnons à leur retour de la découverte et de la conquête des Indes. Après l'île d'Amour et le royaume de coqueterie (décrits dans le volume 26), le séjour de la volupté trouvant naturellement sa place; et l'idée d'unir aux nymphes imortelles de la mer les conquérants de l'Inde, nous a paru des plus heureuses (p. VI).

Notons, toutefois que, dans le sommaire qui précède la page de tître, il est précisé que "L’Ile Enchantée" est à l'origine d'un "épisode de $L a$ Lusiade, traduit du Camoens". ${ }^{86}$

A produção destas e muitas outras obras literárias na esteira de Os Lusíadas é o claro indício de uma aceitação que ultrapassa o âmbito directivo e restritivo da crítica para se instalar na sensibilidade estética

\footnotetext{
${ }^{84}$ cf. SOUSA, 1987, p.272.

${ }^{85}$ cf. SOUSA, 1987, p.272.

${ }^{86}$ apud COUTINHO, 1982, p.531.
} 
dos franceses. Esta é a fase última de qualquer processo de recepção, a partir da qual desaparecem as incertezas sobre a "adopção" ou não de um autor. Diríamos que este complexo processo, que envolve valorações de ordem estética, sócio-cultural e ético-ideológica, assemelha-se, analogamente, ao moroso e também complicado procedimento de beatificação que a Igreja empreende. São muitos os candidatos à santificação, mas muito poucos os deveras canonizados. No universo literário a exigência ainda se torna mais elevada, pois que o "candidato" se sujeita à diacronia. E, por vezes, nos universos da recepção "mudam-se os tempos, mudam-se as vontades". Os tempos não mudaram para Camões, continua com a dimensão de um caso literário transnacional e intercontinental. Permanece como criador estético-literário universal e, por essa razão, agente maior na instituição literária e no seu cânone.

\section{Os Lusíadas, poema universal}

Regressamos ao ponto de partida do nosso estudo: o fenómeno camoniano na sua dimensão receptiva, ou, por outras palavras, o universalismo de Os Lusiadas. Depois de termos feito incursão pelos inícios da difusão de Camões em França, é altura, estabelecendo-se, de resto, um hiato com o parágrafo anterior, de interrogar: - o que é que substancia Os Lusíadas como objecto literário universal?

A resposta tem a ver com o tratamento conferido, por Camões, ao indivíduo e à concretude existencial deste. Homero e Virgílio cantam a lenda; Dante, o Céu e o Inferno; Milton, a génese do Mundo. Camões, mais terreno, aproxima-nos da realidade humana e da sua historicidade. ${ }^{87} \mathrm{~A}$ dimensão humana da epopeia grifa-lhe uma dimensão a-temporal que lhe permite em qualquer realidade histórica auto-validar-se. Os Lusiadas cantam a gloriosa revelação de

${ }^{87}$ cf. SANCEAU, 1980, p.136. 
mundos estranhos, entusiasmam a expansão no desconhecido, mas não ignoram o preço de tais feitos. As imprecações do velho do Restelo à luz da nosso tempo, marcado por guerras, fomes e lástimas à sombra do progresso humano, "ecoam (...) com uma triste actualidade, e mais do que nunca sentimos como Camões pertence não somente a todo o mundo, mas a todos os tempos". ${ }^{8}$

Esse "universalismo humano" encontra-se em cada estância do poema, tenha ela um cariz anedóctico, elegíaco, lírico, lamentoso, exótico ou bucólico. Cada um destes elementos sintoniza um estado anímico, é uma "substância da alma"90 e harmoniza-se numa diversidade unitária "que não é senão (...) a transposição literária da concepção camoniana da unidade que preside ao vasto mundo dos valores do espírito". ${ }^{91}$ É, por essa razão, que Os Lusíadas há muito deixaram de ser simplesmente a corajosa epopeia de um punhado de valorosos aventureiros para ser em toda a sua grandeza "a epopeia do homem". ${ }^{2} \mathrm{~J}$. M. Latino Coelho reconhece, aliás, que apesar da história nacional constituir o principal empenho de Camões, "a Pátria, com ser para o vate o mais religioso e ardente afecto, não é campo assaz desafrontado aos voos do seu espírito largamente filosófico e às aspirações cosmopolitas do seu generoso coração". ${ }^{93}$ Os Lusíadas foram, de facto, impregnados de muito mais, passível de circunscrição em termos de natureza, de amor, de Humanidade,

(...) qualidades eminentes, que tornam os Lusíadas uma criação original e inimitável, deveu a magnífica epopeia o culto patriótico e literário, com que Portugal a tem sempre venerado, como se fora o mágico talismã da sua nacionalidade e a Arca Santa das suas glórias. Dai vem o apreço, com

\footnotetext{
${ }^{88}$ cf. SANCEAU, 1980, p.144.

${ }^{89}$ JANEIRA, 1972, p.347.

${ }^{90}$ JANEIRA, 1972, p.347.

${ }^{91}$ JANEIRA, 1972, p.347.

${ }^{92}$ JANEIRA, 1972, p.347.

${ }^{93}$ COELHO, 1985, p.209.
} 
que os estranhos a têm honrado, significando em versões inumeráveis em todas as linguagens europeias, que se os Lusíadas estão escritos em versos portugueses, o Gama como o Colombo, como Watt, como Stefenson, pertencem à história comum da Civilização, e o Camões, como o Dante, o Homero, Cervantes, ou Shakespeare à literatura da Humanidade. ${ }^{94}$

Além disso, a epopeia de Camões participa do sistema de valores da cultura e civilização europeias:

A primeira chave da universalidade de Camões está em ele ter sabido ser um poeta europeu, quer pelo sentido temporal da revalorização, utilização e criação a partir do património trans-secular da cultura ao seu alcance (e essa era toda a cultura europeia ocidental acumulada, no sentido ilustrado do termo), quer pelo sentido espacial, geo-político se quisermos, de diferenciação do nosso continente como área de solidariedade específica, imperativa, e também cultural e civilizacional, entre as partes que a compunham. ${ }^{95}$

Concomitantemente, como assinala António José Saraiva (1996), Os Lusiadas possuem um objectivismo que resgata a epopeia do tempo. "O tempo é transcendental à esfera constituída pela obra épica" $"$ e limita a sua actuação ao espaço lírico e autobiográfico. Com efeito, a verdade histórica e científica que brota em cada página da epopeia confere-lhe uma objectividade indepentente da subjectividade do leitor, que nem a mitologia, na sua função decorativa e narrativa, contradiz. Os deuses, entidades ficcionais por excelência, "(...) além de serem símbolos de verdades, os deuses eram também máscaras permanentes que funcionavam como protectores contra a caducidade do tempo". ${ }^{97}$

Finalizamos este breve estudo prefigurando um continuar da valoração estético-literária de Os Lusíadas que se acusa na sólida protagonização que Camões desempenha no cânone da Grande

\footnotetext{
${ }^{94}$ COELHO, 1985, p.216, grifos nossos.

${ }^{95}$ MOURA, 1987, p.16.

${ }^{96}$ MOURA, 1987, p.98.

${ }^{97}$ MOURA, 1987, p.105.
} 
Literatura ao lado de Cervantes, Dante, Shakespeare... e poucos mais. Dessa implantação nos diz justamente D. Elaine Sanceau, quando escreve que:

(...) Camões é de todos, é universal. Pertence ao reduzido número dos muitos grandes que não cabem dentro de fronteiras, daqueles que nas asas do génio subiram muito acima das barreiras, todas elas mais ao menos artificiais, que separam a Humanidade, para pairar no empireu onde as almas se encontram na eternidade da poesia universal. ${ }^{98}$

\section{Bibliografia}

AGUIAR E SILVA, Vítor Manuel. Camões: Labirintos e Fascinios. Lisboa: Cotovia, 1994.

ALMEIDA, Justino Mendes de. Quatro Nótulas Camonianas. Revista da Faculdade de Letras, 5ª série, Lisboa, n.13-14, 1990.

Arquivos do Centro Cultural Português. Paris: Fundação Calouste Gulbenkian, 1971.

Arquivos do Centro Cultural Português. Paris: Fundação Calouste Gulbenkian, 1980. (V separata).

Arquivos do Centro Cultural Português. Paris: Fundação Calouste Gulbenkian, 1981.

ASENSI, Manuel. Teoria de la lectura. Para una crítica paradógica. Madrid: Ediciones Hiperión, 1987.

BAR, F. A propos d'épopée. Arquivos do Centro Cultural Português. Paris: Fundação Calouste Gulbenkian, 1980.

BISMUT, Roger. Les Lusiades de Luis de Camões. Paris: Les Belles Lettres, 1954.

BISMUT, Roger. Camões en France. Arquivos do Centro Cultural Português. Paris: Fundação Calouste Gulbenkian, 1981.

98 SANCEAU, 1980, p.155. 
BISMUT, Roger. Camões en procès sous la terreur. Les Rapports Culturels entre le Portugal et la France. Paris: Fondation Calouste Gulbenkian, Centre Culturel Portugais, 1983.

BISMUT, Roger. Uma versão francesa até hoje ignorada de Os Lusíadas. Colóquio Letras, , Lisboa, n.65, jan.1982.

Boletim da Academia Internacional da Cultura Portuguesa, Lisboa, n.8, 1980.

COELHO, J. M. Latino. Luís de Camões. Porto: Lello \& Irmão, 1985. Colóquio Letras, Lisboa, n.100, nov.-dez. 1987.

Colóquio Letras, Lisboa, n.65, jan.1982.

Colóquio Presença de Portugal no Mundo. Lisboa: Academia Portuguesa de História, 1982.

COUTINHO, B. Xavier. Camões no Mundo do Espaço Cultural. Actas do Colóquio Presença de Portugal no Mundo. Lisboa: Academia Portuguesa de História, 1982.

COUTINHO, B. Xavier. Ensaios Varia Camoniana. Porto: Lopes da Silva, 1941.

DELILE, Maria Manuela Gouveia; MINGOCHO, Maria Teresa Delgado. A recepção do teatro de Schiler em Portugal no século XIX. I- O drama Die Rauber. Coimbra: Instituto Nacional de Investigação Científica, Centro de Literatura Portuguesa da Universidade de Coimbra, 1980.

Estudos sobre a projecção de Camões em culturas e literaturas estrangeiras. Lisboa: Acad. das Ciências de Lisboa, 1984. (Separata do volume III d'Os Lusiadas).

Garcia de Orta, Revista da Junta de Investigação de Ultramar, Lisboa, n. especial comemorativo do IV centenário da publicação de Os Lusíadas, 1972.

Há vivo interesse pelo centenário de Os Lusíadas. Permanência, Lisboa, II, p. 22, 1972.

ISER, Wolfang. L'acte de lecture. Théorie de l'effet esthétique. Bruxelles: Pierre Mardaga, 1985. 
JANEIRA, Armando Martins. Camões na Literatura Mundial. Garcia de Orta, Revista da Junta de Investigação de Ultramar, Lisboa, $\mathrm{n}$. especial comemorativo do IV centenário da publicação de Os Lusiadas, 1972.

JAUSS, Hans Robert. La jouissance esthétique. Les expériences fondamentales de la poesis, de l'aisthesis et de la catharsis. Poétique. Théorie de la réception en Allemagne, Paris, n.79, 1979.

JURT, Joseph. (1983). L'esthétique de la réception. Une nouvelle approche de la littérature? Les Lettres Romanes, Paris, v. XXVIII, n. 3 .

LE GENTIL, Georges. Camões, l'oeuvre épique et lyrique. Paris: Hatier-Boivin, 1986.

Les Lusiades par Camões. Lire, n. 247, été 1996.

Les Rapports Culturels entre le Portugal et la France. Paris: Fondation Calouste Gulbenkian, Centre Culturel Portugais, 1983.

LIMA, Luís Costa (org.) A literatura o leitor. Textos de Estética da recepção. Rio de Janeiro: Paz e Terra, 1979.

MACHADO, Álvaro Manuel e PAGEAUX, Daniel-Henri. Da Literatura Comparada à Teoria da Literatura. Lisboa: Edições 70, 1988.

MARTINS, António Coimbra. Esperanças de Abril. Lisboa: Perspectivas e realidades, 1981.

MONTESQUIEU. De l'Esprit des Lois. Tome II. Paris: Garnier Frères, 1973.

MORERI, Luis. El Gran Diccionario Historico. Tomo II. Paris: Hermanos Detournes, 1753.

MOURA, Vasco Graça. Os Penhascos e a Serpente e outros ensaios camonianos. Lisboa: Quetzal, 1987.

Os Lusíadas em França . Público, Porto, n. 2285, 12 jun.1996.

PAGEAUX, Daniel-Henri. Camoens en France. Estudos sobre a projecção de Camões em Culturas e literaturas estrangeiras. Lisboa: Acad. das Ciências de Lisboa, 1984.1984b. 
PAGEAUX, Daniel-Henri. Imagens de Portugal na cultura francesa. Lisboa: Instituto de Cultura e Língua Portuguesa, 1984a

PAGEAUX, Daniel-Henri. Images du Portugal dans les lettres Françaises. Arquivos do Centro Cultural Português. Paris: Fundação Calouste Gulbenkian, 1971.

Poétique. Théorie de la réception en Allemagne, Paris, n.79, 1979.

QUEIRÓs, Luís Miguel. O regresso de Luíz Vaz. Público, Porto, n. 2228, 16 abr. 1996.

ROIG, Adrian. Echanges Littéraires entre le Portugal et la France sur le thème de Inês de Castro. Les Rapports Culturels entre le Portugal et la France. Paris: Fondation Calouste Gulbenkian, Centre Culturel Portugais, 1983.

SAAVEDRA, Miguel Cervantes. O Engenhoso Fidalgo Dom Quixote de la Mancha. Vol.II. Porto: Imprensa da Companhia Literária, 1878.

SALOMON, P. A actualidade portuguesa em França no século XVIII. Biblos, Revista da Faculdade de Letras da Universidade de Coimbra, v.IV, 1928.

SANCEAU, Elaine. Camões Nacional e Universal. Academia Internacional da Cultura Portuguesa, Academia Internacional da Cultura Portuguesa, Lisboa, n.8, 1980.

SARAIVA, António José. (1987). Função e Significado do Maravilhoso n'Os Lusíadas. Colóquio Letras, Lisboa, n.100, nov.-dez. 1987.

SARAIVA, António José. Estudos sobre a Arte d'Os Lusiadas. Lisboa: Gradiva, 1996.

SOUSA, Maria Leonor Machado de. Inês de Castro - Um Tema Português na Europa. Viseu: Edições 70, 1987.

STEINMETZ, Horst. (). Réception et interprétation, Théorie de la Littérature. Paris: Editions A. et J. Picard, 1981.

STIERLE, Karlheinz. Que significa a recepção dos textos ficcionais? In: LIMA, Luís Costa (org.) A literatura o leitor. Textos de Estética da recepção. Rio de Janeiro: Paz e Terra, 1979.

Théorie de la Littérature. Paris: Editions A. et J. Picard, 1981. 


\section{Resumo}

Pretendeu-se, com este estudo, descrever, nos seus aspectos mais relevantes, a recepção de Os Lusíadas em França até ao século XVIII, de forma a melhor entender o prestígio que este autor e a sua epopeia, actualmente, gozam nesse país.

\section{Résumé}

On a prétendu, avec cet étude, décrire, dans ses aspects les plus importants, la réception de Os Lusiadas en France jusqu'au siècle XVIII, de manière à mieux comprendre le préstige que cet auteur et son épopée, actuellement, jouissent dans ce pays. 